\title{
Vertical distribution of fish biomass in hypoxic waters on the Gulf of Mexico shelf
}

\author{
Elliott L. Hazen ${ }^{1, *}$, J. Kevin Craig ${ }^{2}$, Caroline P. Good ${ }^{1}$, Larry B. Crowder ${ }^{1}$ \\ ${ }^{1}$ Nicholas School of the Environment and Earth Sciences, Duke University Marine Laboratory, 135 Duke Marine Lab Road, \\ Beaufort, North Carolina 28516-9721, USA \\ ${ }^{2}$ Coastal and Marine Laboratory, Florida State University, 3618 Highway 98, St. Teresa, Florida 32358-2702, USA
}

\begin{abstract}
Hypoxic bottom waters (dissolved oxygen $\leq 2.0 \mathrm{mg} \mathrm{l}^{-1}$ ) in the northwestern Gulf of Mexico are largely due to nutrient loading from the Mississippi-Atchafalaya watershed. Loss of benthic habitat has been documented in bottom trawl surveys, but little is known about the effect of hypoxia on the vertical distribution of fish biomass. To investigate these effects, we used a $120 \mathrm{kHz}$ split-beam echosounder to compare the vertical distribution of fish biomass at stations with hypoxic bottom waters to those with normoxic bottom waters. We also used paired mongoose and flat trawls to assess species composition, and a CTD to measure physical characteristics of the water column. Atlantic croaker Micropogonias undulatus, Atlantic bumper Chloroscombrus chrysurus, and anchovies (Anchoa spp.) comprised $92 \%$ (by number) of fish sampled. Dissolved oxygen, time of day, and depth within the water column were the major factors explaining variation in acoustic biomass. Stations inside and outside of the hypoxic zone had similar overall density but differed in vertical distribution. Hypoxic stations had greater biomass in the upper $7 \mathrm{~m}$ of the water column and much less biomass below $13 \mathrm{~m}$ compared to normoxic stations, consistent with aggregation of organisms above the bottom hypoxic layer. We did not find evidence of strong aggregation at the hypoxic edge throughout the entire water column. While the pelagic habitat is not directly impacted by lowoxygenated bottom water, hypoxia can induce vertical or horizontal displacement of fish mediating potential indirect bioenergetic or trophic interactions.
\end{abstract}

KEY WORDS: Hypoxia $\cdot$ Micropogonias undulatus $\cdot$ Chloroscombrus chrysurus · Gulf of Mexico · Acoustics - Spatial structure - Vertical distribution · Food web · Habitat compression

\section{INTRODUCTION}

Excess nutrient loading from anthropogenic activities has altered the oxygen budgets of many coastal ecosystems such that hypoxia [dissolved oxygen (DO) $\leq 2 \mathrm{mg} \mathrm{l}^{-1}$ or $\leq 30 \%$ saturation] has increased in severity, spatial extent, and temporal duration (Cloern 2001, Diaz 2001, Diaz \& Rosenberg 2008). Hypoxia arises when excess organic matter is subject to aerobic decomposition in bottom waters that are isolated from reaeration, typically by thermohaline stratification. The spatial and temporal dynamics of hypoxia are highly variable among systems, but a common feature is the typical confinement of low oxygen to bottom waters, with rare extension either fully to surface waters or to the shoreline. Thus, some amount of oxygenated refuge habitat is typically available to mobile organisms capable of behaviorally avoiding hypoxia. While hypoxic areas occur naturally in several marine ecosystems and sometimes harbor diverse resident communities (e.g. deep ocean oxygen minimum zones; Rogers 2000, Helly \& Levin 2004), hypoxia due to anthropogenic nutrient loading in shallow coastal environments is increasing and can limit the available benthic habitat (Diaz 2001, Rabalais et al. 2002). A better understanding of behavioral avoidance responses to hypoxia is needed because indirect effects mediated by these avoidance behaviors and associated shifts in 
spatial distribution are thought to be a major pathway by which hypoxia can impact mobile species (Craig et al. 2001, Breitburg 2002, Craig et al. 2005) .

Mobile fishes and invertebrates typically have well developed sensory systems that allow detection and avoidance of water with low DO (Wannamaker \& Rice 2000, Wu 2002). Sensitivity to hypoxia as well as the capacity to avoid it can vary among species (Bell \& Eggleston 2005), developmental stages (Breitburg et al. 1997), between sexes, with reproductive state (Breitburg 1992), and with body size (Burleson et al. 2001). When exposed to hypoxia, organisms may move horizontally to oxygenated refuges that often occur in shallow habitats where mixing is sufficient to aerate the water (Eby \& Crowder 2002, Bell \& Eggleston 2005, Stierhoff et al. 2006), or to deeper offshore habitats beyond the influence of the stratification and nutrients necessary for hypoxia to develop (Craig \& Crowder 2005). For example, based on fishery-independent trawl surveys, Craig \& Crowder (2005) showed that brown shrimp and Atlantic croaker on the northwestern Gulf of Mexico shelf avoid hypoxic water and occur at high densities in nearby oxygenated edge habitats, with abundance declining rapidly with increasing distance from the edge. Alternatively, because hypoxia is typically constrained to the bottom portion of the water column by density stratification, organisms may also move vertically to avoid the low-oxygen water near the bottom (Patriquin 1967, Aku et al. 1997, Keister et al. 2000, Taylor \& Rand 2003). Shifts in spatial distribution that result from behavioral avoidance of hypoxia often have implications for foraging (Brandt \& Mason 2003), growth (Eby et al. 2005, Stierhoff et al. 2006), and exposure to predators (Lenihan et al. 2001, Domenici et al. 2007). These effects may differ between organisms that move vertically and those that move horizontally to avoid low oxygen.

The continental shelf of the northwestern Gulf of Mexico currently experiences the largest seasonal hypoxic zone in the western hemisphere (Rabalais et al. 2002, Turner et al. 2008). Hypoxia in the Gulf is a coastal phenomenon associated with high freshwater and nutrient inputs from the Mississippi-Atchafalaya river system, which drains about $41 \%$ of the continental United States. It has been documented as early as February and can persist until October, but typically occurs from mid-May to mid-September (Rabalais et al. 2002). Since the early 1980 s, annual hydrographic surveys have shown that the spatial extent of the hypoxic zone can range from $40 \mathrm{~km}^{2}$ to over $20000 \mathrm{~km}^{2}$ in some years (Rabalais et al. 2002, Craig et al. 2005). Hypoxia typically occurs between depths of 5 to $30 \mathrm{~m}$ on the inner Louisiana shelf, with oxygenated habitat both inshore and offshore of the hypoxic region. It typically extends vertically over the bottom 1 to $3 \mathrm{~m}$ of the water column, but has been documented to occupy up to $80 \%$ of the water column (Rabalais et al. 2001).

The 3D distribution of fish is difficult to quantify using traditional tools such as trawls. Fisheries acoustics is a minimally invasive technique for quantifying both the horizontal and vertical distribution of biomass in the water column at relatively small spatial scales (Simmonds \& MacLennan 2005). Combining acoustics with net sampling can provide information on species composition as well as on the fine-scale vertical and horizontal distribution of biomass. We used this approach on the northwestern Gulf of Mexico shelf to test the 3 following hypotheses: (1) the mean density of fish in the water column is lower within the hypoxic zone compared to adjacent normoxic waters, consistent with horizontal displacement of organisms within the water column from areas with hypoxic bottom water; (2) the horizontal distribution of fish biomass within the water column is highest near the hypoxic edge (1.9 to $2.1 \mathrm{mg}$ $\mathrm{O}_{2} \mathrm{l}^{-1}$ ) and declines with increasing distance from the edge, as found by Craig \& Crowder (2005) for the bottom meter of the water column based on trawl surveys at large spatial scales; and (3) the vertical distribution of fish biomass is more aggregated in areas overlying hypoxic bottom waters compared to areas where the entire water column is normoxic, consistent with vertical shifts in distribution in response to bottom water hypoxia. We used hydrographic, acoustic, and bottom trawl data collected in July 2004 from the northwestern Gulf of Mexico shelf to test these hypotheses.

\section{MATERIALS AND METHODS}

Acoustic, trawl, and hydrographic surveys. We used fisheries acoustics in conjunction with a bottom trawl and hydrographic survey on the Louisiana continental shelf (Fig. 1) from July 20 to August 1, 2004 aboard the RV 'Tommy Munro' (30 m vessel length). A towed body with a $120 \mathrm{kHz}$ SIMRAD EK-60 transducer was suspended from a J-frame $\sim 3 \mathrm{~m}$ from the port side of the vessel. We measured echo intensity at a frequency of 10 pings $\mathrm{s}^{-1}$ and pulse width of $256 \mu$ s during the 20 min trawl duration at a subset of stations (see below). The echosounder was calibrated with a $23 \mathrm{~mm}$ copper sphere of known target strength $(-40.4 \mathrm{~dB}$ at $120 \mathrm{kHz}$; Foote 1982) before and after the $13 \mathrm{~d}$ survey. Acoustic data were collected at a threshold of $-90 \mathrm{~dB}$ to exclude smaller targets and were post-processed using SIMRAD's Sonar5 Pro (Balk 2001). The bottom was automatically detected and corrected by hand using a backstep of $0.5 \mathrm{~m}$. Acoustic and trawl data were collected synoptically at discrete stations from 12:00 to 18:00 h (day) and from 00:00 to 06:00 h (night) daily from July 20 to August 1 . Acoustic data from each sta- 


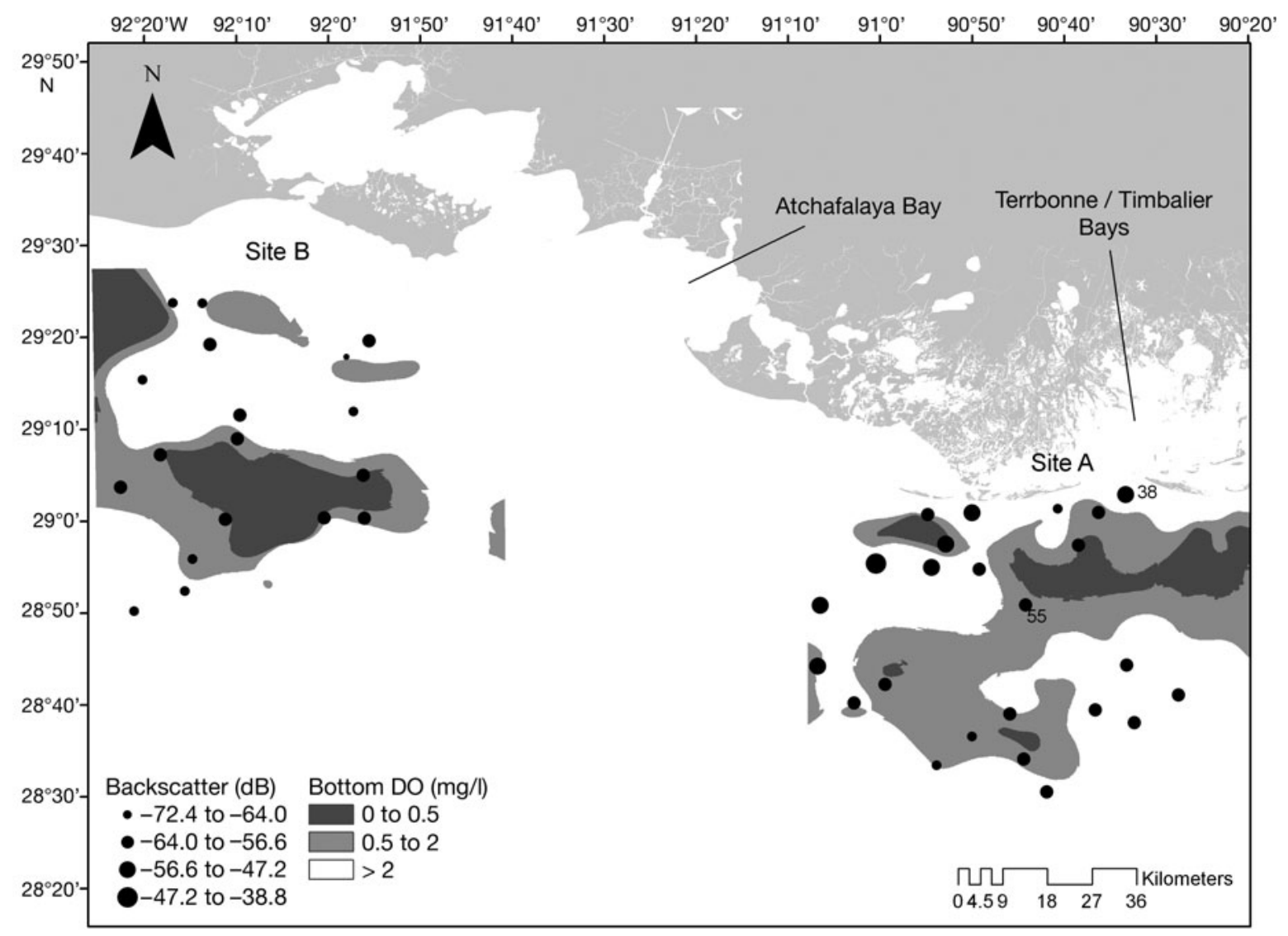

Fig. 1. Stations sampled acoustically on the Louisiana continental shelf during July 2004. (•) Mean volume backscatter strength $(\mathrm{dB})$ ranging from high to low (small to large points). Bottom dissolved oxygen was interpolated from a larger number of hydrographic stations $(n=116)$. Sites $A$ and B and Stns 55 and 38 are marked for reference

tion were binned vertically into $1 \mathrm{~m}$ intervals and averaged horizontally over the length of the trawl (mean trawl length $=1.84 \mathrm{~km}$ ) prior to analysis.

Trawl surveys were conducted at each station using a $12.8 \mathrm{~m}$ shrimp trawl and a $12.8 \mathrm{~m}$ mongoose trawl towed in tandem from either side of the vessel. Each trawl was comprised of $5.1 \mathrm{~cm}$ webbing in the body and $4.1 \mathrm{~cm}$ webbing at the cod end, and fitted with mud rollers, $2.4 \times 1 \mathrm{~m}$ wooden chained doors, and a tickler chain. The mongoose trawl had a bib attached to a third bridle cable to sample a larger portion of the water column ( 3 to $4 \mathrm{~m}$ from the footrope to the top of the bib), but was otherwise identical to the shrimp trawl. The height of the shrimp trawl was limited to $\sim 1 \mathrm{~m}$ from the footrope to the headrope by the height of the doors. Trawl tows were conducted parallel to depth contours for 20 min at a vessel speed of $\sim 3$ knots. The beginning and ending locations for each trawl tow were recorded with a handheld GPS. For some stations, trawl catches were randomly subsampled based on weight ( $23 \%$ of stations); otherwise, the entire catch was processed. All species in the catch or the subsample were identified, measured (total length to the nearest millimeter), and counted. Catches were adjusted to the total weight of the catch (if subsampled) and to a standard tow length of $1.6 \mathrm{~km}$ (the median tow distance) based on the straight-line distance between the beginning and ending trawl locations.

A CTD was used to profile physical characteristics of the water column at the beginning and end of each trawl tow. Profiles were taken with a SeaBird 911-Plus (SeaBird Electronics) equipped with an SBE 43 DO sensor. DO $\left(\mathrm{mg} \mathrm{l}^{-1}, \%\right.$ saturation), temperature $\left({ }^{\circ} \mathrm{C}\right)$, and salinity were binned into $1 \mathrm{~m}$ depth bins from the bottom to the surface prior to analysis. We used average values from the bottom meter of the profile to characterize bottom conditions.

We sampled 2 study sites on the western Louisiana shelf (Fig. 1). Site A off Terrebonne and Timbalier Bays is heavily influenced by the Mississippi river and has experienced severe bottom-water hypoxia in $\geq 75 \%$ of years since 1985 based on shelfwide mapping surveys in July (Rabalais et al. 2002); we completed acoustics, trawls and CTDs at 24 stations at this site. We also sampled a second region further west that is heavily influenced by water from Atchafalaya Bay and has experienced bottom-water hypoxia in $\geq 50 \%$ of years since 1985; here we completed acoustics, trawls and 
CTDs at 17 stations. Stations were chosen by randomly sampling a nested grid designed to map the general distribution of hypoxia in the region $\left(10 \mathrm{~km}^{2}\right.$ grid cells $)$ as well as the locations of the inshore and offshore hypoxic edges $\left(2.5 \mathrm{~km}^{2}\right.$ grid cells). Stations were sampled in an east to west direction by repeatedly traversing the inshore-offshore distribution of hypoxia across a depth range of 2 to $35 \mathrm{~m}$. Acoustics were used at a subsample of the stations (shown in Fig. 1) during fixed daytime and nighttime intervals (12:00 to $18: 00 \mathrm{~h}$ and 00:00 to 06:00 h).

Analysis. Mean volume backscatter strength (MVBS or $\mathrm{S}_{\mathrm{v}}$ ) was measured in logarithmic units of decibels (dB) where increasing negative values correspond to lower biomass. For statistical analysis, means and variances were calculated from linear units of backscatter, the volume backscatter coefficient $\left(\mathrm{s}_{\mathrm{v}}=10^{\mathrm{S}_{\mathrm{v}} / 10}\right)$, and converted to decibels for display. We did not convert data from acoustic backscatter to absolute biomass because catch data were only available for the bottom few meters and correlations between trawl catches and acoustic backscatter were relatively weak. For consistency, we use the term backscatter (MVBS or $\mathrm{S}_{\mathrm{v}}$ ) to refer to the thresholded and binned acoustic data (see MacLennan et al. 2002), but use biomass to refer to the organisms.

We investigated relationships between acoustic biomass and the following environmental variables: DO $\left(\mathrm{mg} \mathrm{l}^{-1}\right)$, temperature $\left({ }^{\circ} \mathrm{C}\right)$, and salinity (all averaged over $1 \mathrm{~m}$ vertical depth bins of the water column), thickness of the bottom hypoxic layer (m), time of day (categorical; day $=12: 00$ to $18: 00 \mathrm{~h}$, night $=00: 00$ to 06:00 h), vertical depth bin within the water column $(\mathrm{m})$, distance from the hypoxic edge (m), and absolute bottom depth $(\mathrm{m})$. The hypoxic edge was defined as the band where DO concentration averaged over the bottom meter was between 1.9 and $2.1 \mathrm{mg} \mathrm{l}^{-1}$ based on a spatial interpolation. We interpolated bottom DO separately for Sites A and B using a basic minimum curvature spline function with anisotropy in ArcGis 9.1 (projection: Lambert Conformal Conic, datum: NAD 1983, ESRI). This method is an exact deterministic interpolator and requires no assumptions about the input data. The level of anisotropy that minimized the root mean square error was chosen. Distance from each station to the hypoxic edge was calculated using ArcGIS 9.1 (ESRI). The thickness of the hypoxic zone was calculated as the vertical distance from the bottom to the $2.0 \mathrm{mg} \mathrm{l}^{-1}$ oxycline averaged between the beginning and ending CTD profiles.

Generalized additive models (GAMs) are a nonparametric partial regression approach that provides a graphical and statistical analysis of potential nonlinear relationships without a priori assumptions of a particular functional form (Hastie \& Tibshirani 1990). We used
GAMs to investigate the relationship between acoustic biomass, environmental, and geographic variables assuming a Gaussian distribution for the error term and an identity link function. To account for autocorrelation in acoustic biomass among adjacent vertical depth bins and among stations, we expanded the GAM into a mixed model (GAMM) by including station as a random effect and a first-order correlation function in the error term (Lin \& Zhang 1999, Wood 2006). We constructed GAMMs separately for stations with $>2.0 \mathrm{mg}$ $\mathrm{l}^{-1}$ DO and stations with $\leq 2.0 \mathrm{mg} \mathrm{l}^{-1}$ DO to determine if the relationship of backscatter with environmental variables varied between stations with hypoxic and normoxic bottom waters. GAMMs were fitted in $\mathrm{R}$ (R Development Core Team 2005) using the mgcv package (version 1.4-1, Wood 2006).

We also used Mantel's test to investigate the significance of relationships between backscatter and the environmental variables (Mantel 1967). Mantel's test is a nonparametric partial regression approach based on dissimilarity matrices of predictor and response variables rather than the actual variables themselves. One advantage of Mantel's test over traditional regression approaches is that it explicitly accounts for spatial autocorrelation in both predictor and response variables as well as intercorrelations among predictor variables. Unlike GAMs, Mantel's test assumes a linear relationship among dissimilarity matrices. Mantel's tests were performed using the ecodist package (1.1.3, Goslee \& Urban 2007) in S-Plus version 7.0 (Insightful, 2004).

We used ANOVAs to determine whether (1) the mean density of biomass in the water column $\left(\mathrm{dB} \mathrm{m}^{-1}\right)$ differed inside and outside of the geographic bounds of the hypoxic zone, and (2) the distribution of biomass above and below the pycnocline differed between hypoxic and normoxic stations. Data were tested for normality and homogeneity of variance using Q-Q plots and standardized residuals. For (2) above, the response variable was the log-transformed ratio of backscatter above divided by backscatter below the pycnocline, with the presence versus absence of bottom water hypoxia as a categorical predictor variable. In addition, only stations with bottom depths between $5 \mathrm{~m}$ and $20 \mathrm{~m}(\mathrm{n}=25)$ were included in this analysis to minimize the potentially confounding effect of depth and because the pycnocline was readily discernible at this depth range.

\section{RESULTS}

Of the 41 stations sampled with acoustics, 22 were outside the hypoxic zone in depths of 3 to $31 \mathrm{~m}$ and bottom oxygen levels of 2.0 to $8.7 \mathrm{mg} \mathrm{l}^{-1}$. Nineteen stations were inside the hypoxic zone in depths of 5 to 
$24 \mathrm{~m}$ and bottom oxygen levels of 0.2 to $1.9 \mathrm{mg}$ $\mathrm{l}^{-1}$ (Fig. 1). Although the number of acoustic stations sampled at day (22) and night (19) was similar, there were more hypoxic than normoxic stations sampled at night (12 vs. 7). The thickness of the bottom hypoxic layer was between 0.5 and $6 \mathrm{~m}$ with a mean of $3.3 \mathrm{~m}$, and extended over up to $48 \%$ of the water column (mean percentage of the water column $=15.5$ ). There was no significant difference in biomass density ( $\mathrm{dB} \mathrm{m}^{-1}$ of water column) between hypoxic (mean: $-59.5 \mathrm{~dB}$ ) and normoxic stations (mean: $-56.6 \mathrm{~dB} ;$ ANOVA, $F_{1,40}=2.37, \mathrm{p}=0.13$ ).

Species composition in trawl catches varied among acoustic stations but was typically dominated by Atlantic bumper Chloroscombrus chrysurus, and Atlantic croaker Micropogonias undulatus (Fig. 2). These 2 species combined accounted for 71 and $67 \%$ (by number) of total catches for hypoxic and for normoxic stations, respectively. Overall catch per unit effort (CPUE) was greater at night than during the day, particularly at hypoxic stations. Other commonly caught fish species in order of abundance included striped, dusky, and bay anchovy (Anchoa hepsetus, A. lyolepis, A. mitchilli), silver and white sea trout (Cynoscion nothus, C. arenarius), spot, banded, and star drum (Leiostomus xanthurus, Larimus fasciatus, Stellifer lanceolatus), and butterfish Peprilus burti. Atlantic bumper were on average $\sim 1.5 \times$ more abundant than croaker particularly inshore $(<4 \mathrm{~km}, 68 \%$ of total catch), while croaker were more abundant offshore $(>4 \mathrm{~km}, 44 \%$ of total catch). Species composition at normoxic stations was typically more diverse but was dominated by bumper (59\% of total catch) and croaker (24\%). Anchovies were particularly abundant at some of the normoxic stations relative to hypoxic stations (5 vs. $0.3 \%$ ). Backscatter in the bottom $3 \mathrm{~m}$ of the water column was positively but weakly correlated with CPUE from the trawls; the relationship was significant for the flat trawl $\left(\mathrm{r}^{2}=0.12, \mathrm{p}=0.009, \mathrm{n}=41\right)$ and marginally nonsignificant for the mongoose trawl $\left(\mathrm{r}^{2}=0.032, \mathrm{p}=\right.$ 0.09, $\mathrm{n}=41$ ).

To investigate the relationship between acoustically detected biomass and environmental variables, GAMMs were fitted separately for stations with hypoxic bottom waters and those with normoxic bottom waters (Table 1, Fig. 3). At both normoxic and hypoxic stations, backscatter increased monotonically from the lowest DO levels (hypoxic stations: $0.46 \mathrm{mg}$ $\mathrm{l}^{-1}$, normoxic stations: $2.37 \mathrm{mg} \mathrm{l}^{-1}$ ) up to $4-6 \mathrm{mg} \mathrm{l}^{-1}$, and then leveled off at higher DO (Fig. 3). At normoxic stations, biomass was relatively evenly distributed
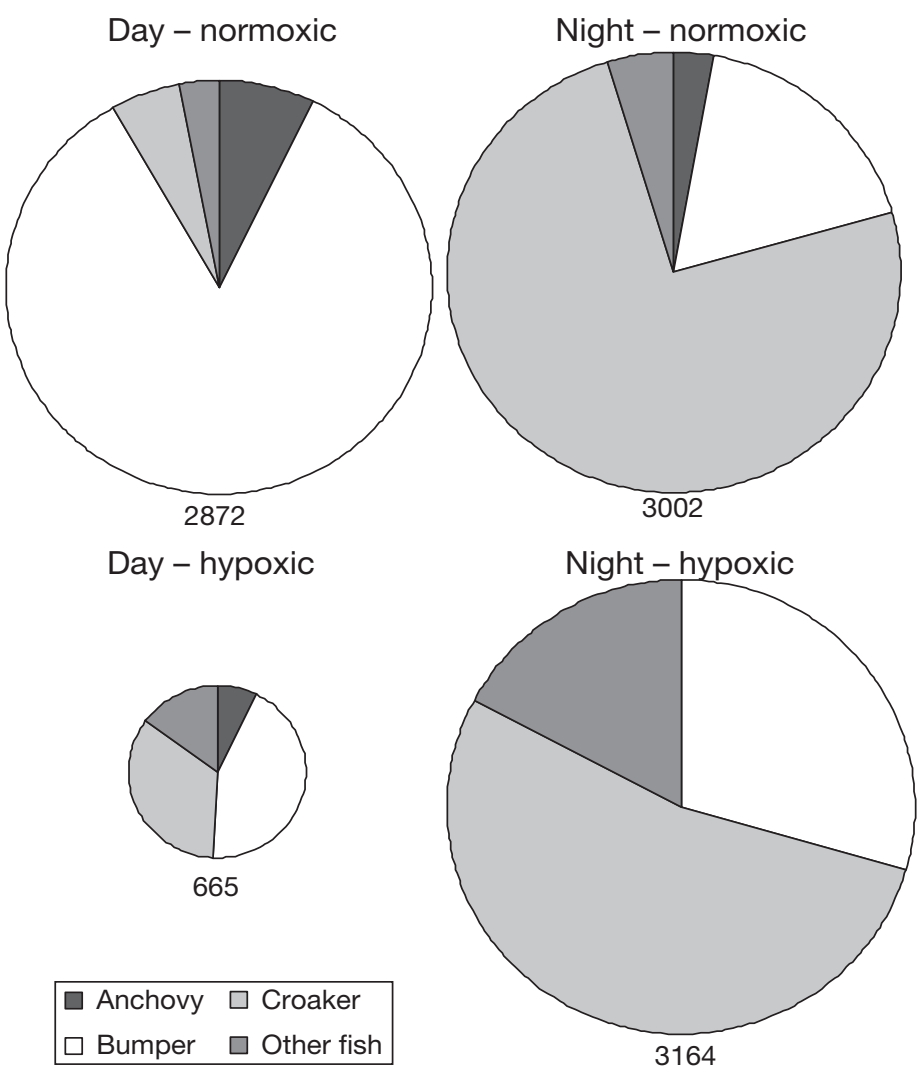

Fig. 2. Species composition of fauna from bottom trawls towed synoptically during acoustic sampling. Trawl results are split by species for normoxic day, normoxic night, hypoxic day, and hypoxic night stations and scaled by total catch. Circle size is proportional to the average catch per unit effort (CPUE) from paired trawls (flat and mongoose) combined. Average tow distance was $1.8 \mathrm{~km}$. Mean CPUE is shown below each chart

Table 1. Test statistics ( $F, t$-value) and probability values for the nonlinear and linear effects of each environmental variable on acoustic backscatter from the Generalized Additive Mixed Model (GAMM) for normoxic stations and hypoxic stations. Statistically significant values $(p<0.05)$ are shown in bold. NA: not applicable

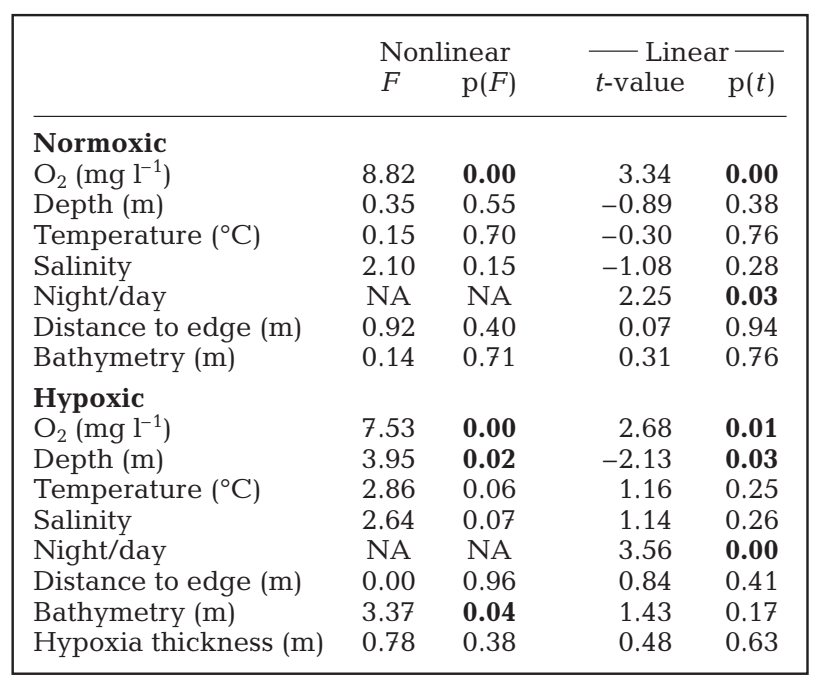


a)
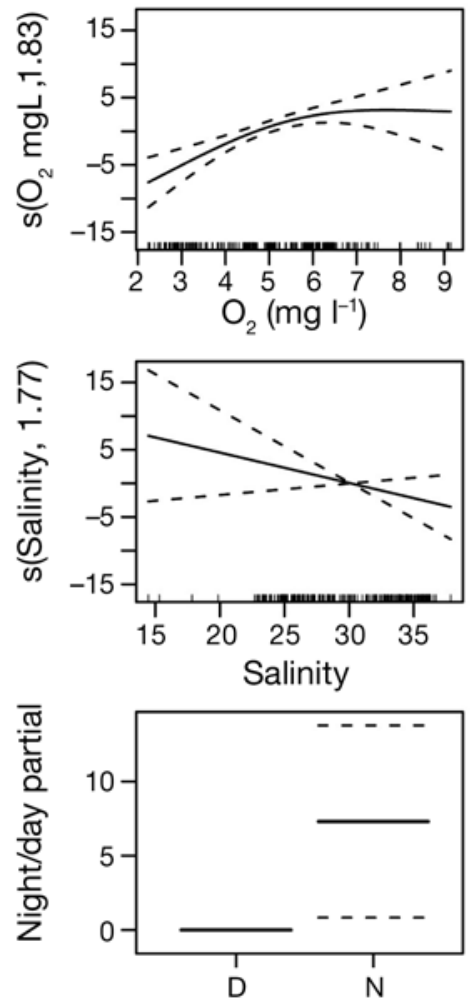

Night/day

b)
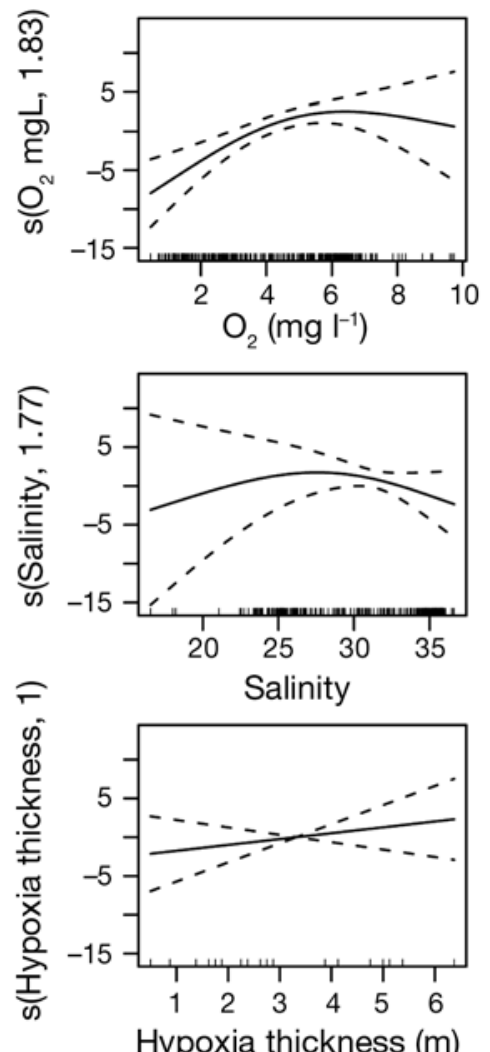
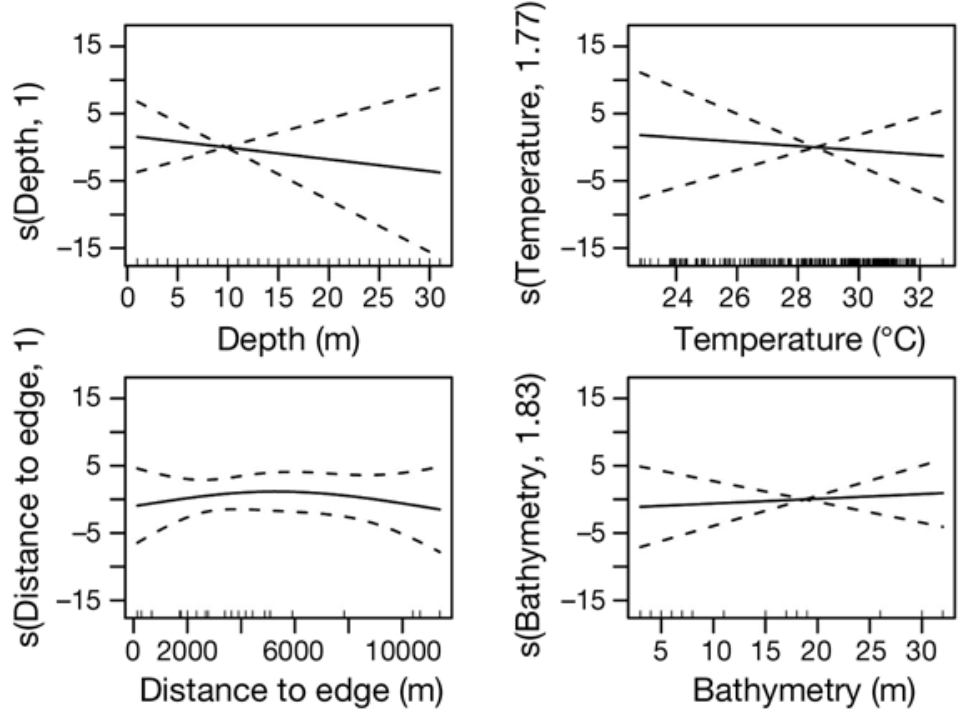
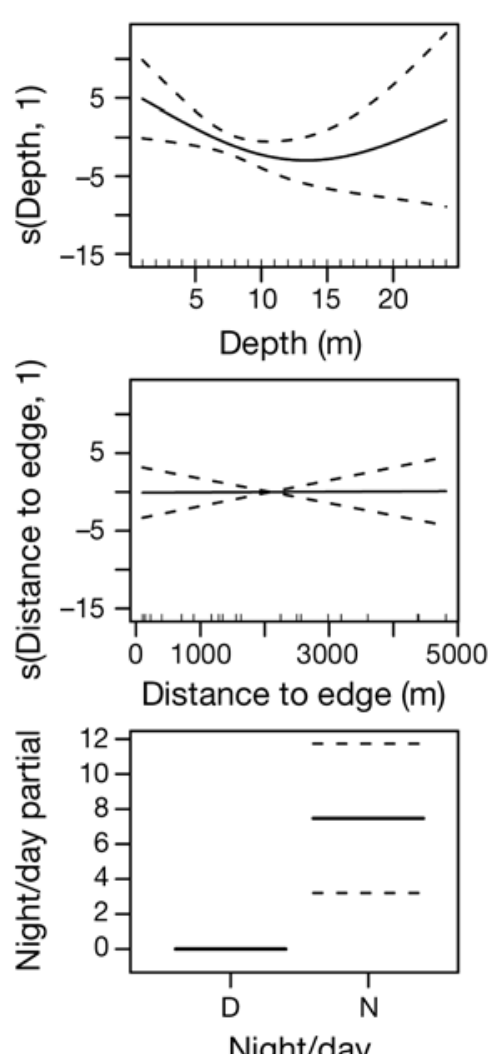
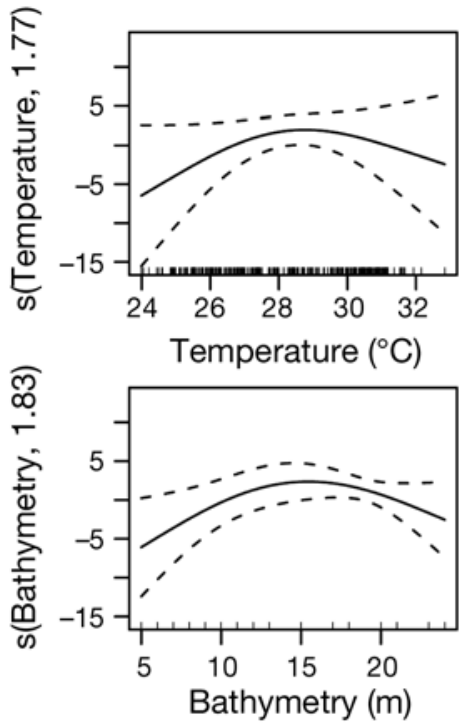

Fig. 3. Generalized additive mixed model (GAMM) for (a) normoxic, and (b) hypoxic stations. Plots show the effects of dissolved oxygen $\left(\mathrm{O}_{2}\right)$, depth bin within the water column (Depth), temperature, salinity, distance to the hypoxic edge, absolute water depth (Bathymetry), thickness of the bottom hypoxic layer (Hypoxia thickness; for hypoxic stations only), and time of day on acoustic backscatter. Degrees of freedom for each spline(s) smooth are given on the $y$-axis. Dotted lines are 2 SEs of the mean response. Rugplot on the $x$-axis indicates sample sizes. Station was entered into the model as a random variable with a first-order autocorrelation term to account for correlation among adjacent depth bins 
throughout the water column although there was a nonsignificant trend toward higher biomass near the surface. In contrast, when bottom waters were hypoxic, backscatter was highest near the surface, declined down to $\sim 10 \mathrm{~m}$ depth, and then leveled off or increased slightly toward the bottom. Relationships with temperature, salinity, and depth were relatively weak and generally not significant, particularly for normoxic stations. Similarly, there was no significant relationship between backscatter and the thickness of the bottom hypoxic layer or distance to the hypoxic edge. Backscatter was significantly higher at night than during the day at both hypoxic and normoxic stations.

Results from Mantel's tests were consistent with those from GAMMs (Table 2, Fig. 4). All of the environmental variables were spatially autocorrelated, with the strength of the autocorrelation varying by an order of magnitude ( $r=0.012$ to 0.11 ). Simple pairwise crosscorrelations (Pearson correlation coefficients) showed variability in correlation among the measured environmental variables $\left(r^{2}=0.01\right.$ to 0.79$)$. There were particularly strong negative correlations between temperature and salinity $\left(\mathrm{r}^{2}=0.79\right)$, positive correlations between DO and temperature $\left(\mathrm{r}^{2}=0.66\right)$, and a weak negative correlation between hypoxia thickness and DO $\left(\mathrm{r}^{2}=0.09\right)$. After accounting for spatial autocorrela-

Table 2. Mantel $r$ coefficients and p-values (in parentheses) for Mantel regressions of acoustic density: Column 1 is the simple regression of acoustic density on each variable (env = environmental); Column 2 is the simple regression of each variable on space; Column 3 is the partial regression of acoustic density on each variable controlling for spatial autocorrelation; and Column 4 is the partial regression of acoustic density on each variable controlling for both spatial and among-variables correlation. $\mathrm{ns}=$ nonsignificant

\begin{tabular}{|c|c|c|c|c|}
\hline & $\begin{array}{l}\text { Simple } \\
\text { (env) }\end{array}$ & $\begin{array}{l}\text { Simple } \\
\text { (space) }\end{array}$ & $\begin{array}{l}\text { Partial } \\
\text { (space) }\end{array}$ & $\begin{array}{l}\text { Pure partial } \\
\text { (space/env) }\end{array}$ \\
\hline Acoustic densi & & $\begin{array}{c}0.027 \\
(<0.001)\end{array}$ & & $\begin{array}{c}0.02 \\
(0.005)\end{array}$ \\
\hline Oxygen & $\begin{array}{c}0.266 \\
(<0.001)\end{array}$ & $\begin{array}{c}0.012 \\
(0.04)\end{array}$ & $\begin{array}{c}0.266 \\
(<0.001)\end{array}$ & $\begin{array}{c}0.174 \\
(<0.001)\end{array}$ \\
\hline Bin depth & $\begin{array}{c}0.247 \\
(<0.001)\end{array}$ & $\begin{array}{c}0.04 \\
(<0.001)\end{array}$ & $\begin{array}{c}0.246 \\
(<0.001)\end{array}$ & $\begin{array}{c}0.15 \\
(<0.001)\end{array}$ \\
\hline Temperature & $\begin{array}{c}0.219 \\
(<0.001)\end{array}$ & $\begin{array}{c}0.042 \\
(<0.001)\end{array}$ & $\begin{array}{c}0.217 \\
(<0.001)\end{array}$ & ns \\
\hline Salinity & $\begin{array}{c}0.188 \\
(<0.001)\end{array}$ & $\begin{array}{r}0.035 \\
(<0.001)\end{array}$ & $\begin{array}{c}0.187 \\
(<0.001)\end{array}$ & ns \\
\hline Time of day & $\begin{array}{r}0.0842 \\
(<0.001)\end{array}$ & $\begin{array}{c}0.038 \\
(<0.001)\end{array}$ & $\begin{array}{r}0.0833 \\
(<0.001)\end{array}$ & $\begin{array}{c}0.087 \\
(<0.001)\end{array}$ \\
\hline $\begin{array}{l}\text { Hypoxia } \\
\text { thickness }\end{array}$ & ns & $\begin{array}{c}0.05 \\
(<0.001)\end{array}$ & $\mathrm{ns}$ & $\mathrm{ns}$ \\
\hline Bathymetry & $\begin{array}{c}0.12 \\
(<0.001)\end{array}$ & $\begin{array}{c}0.11 \\
(<0.001)\end{array}$ & ns & ns \\
\hline $\begin{array}{l}\text { Distance from } \\
\text { edge }\end{array}$ & $\mathrm{ns}$ & $\begin{array}{c}0.06 \\
(<0.001)\end{array}$ & $\mathrm{ns}$ & ns \\
\hline
\end{tabular}

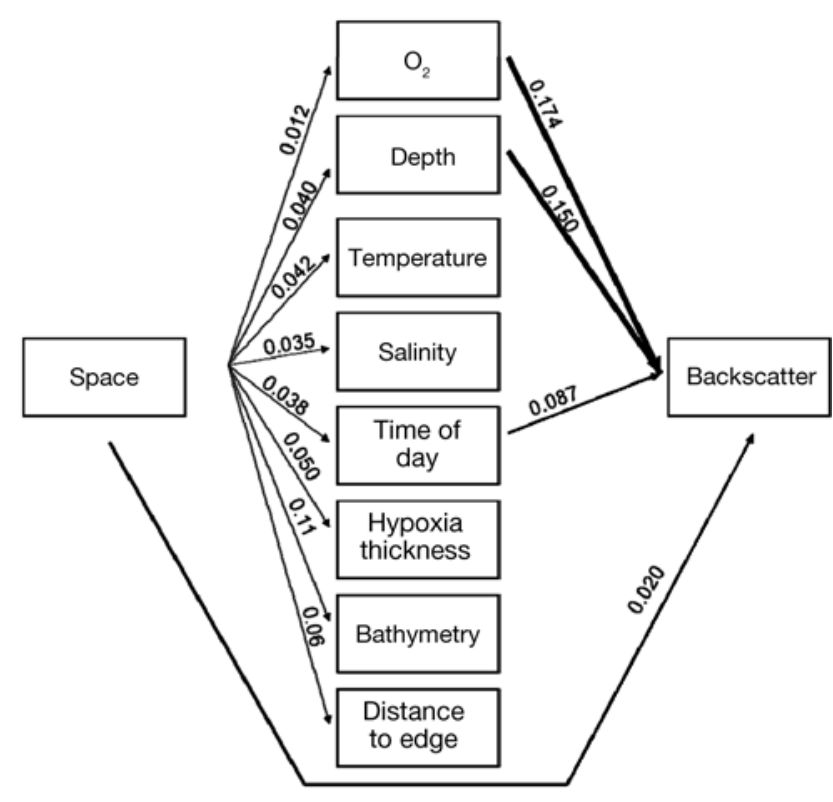

Fig. 4. Mantel path diagram depicting the relationship between acoustic backscatter, environmental variables, and spatial location. Lines indicate significant simple and partial correlations $(\mathrm{p}<0.05)$. Numbers above each line are Mantel $r$ correlation coefficients. Arrows originating from 'space' show the spatial autocorrelation within each environmental variable and in acoustic backscatter. Arrows originating from the environmental variables show the pure partial effect of the variable on acoustic backscatter after accounting for the effects of spatial autocorrelation and intercorrelation among variables. Arrow thickness is proportional to the strength of the relationship (r). The bottom arrow shows residual spatial structure in acoustic backscatter that is not accounted for by the environmental variables

tion and intercorrelations among variables, DO, depth bin within the water column, and time of day had significant effects on backscatter (Fig. 4, Table 2). Pure partial correlations with DO and depth bin, however, were about twice as strong as the pure partial correlation with time of day. Even after accounting for these effects, a small but significant residual spatial structure in backscatter remained.

For illustration purposes, we chose 2 representative stations that had similar bottom depths (6 vs. $7 \mathrm{~m}$ ) and were sampled at similar times (16:00 vs. 13:00 h), but experienced contrasting bottom oxygen conditions. Stn 55 was located at the hypoxic edge as indicated by bottom DO of $1.7 \mathrm{mg} \mathrm{l}^{-1}$ (1 $\mathrm{m}$ thick) at the beginning location and bottom DO of $4.2 \mathrm{mg} \mathrm{l}^{-1}$ at the end of the station (20 min duration). In contrast, Stn 38 was located in well oxygenated bottom water (mean of $5.8 \mathrm{mg} \mathrm{l}^{-1}$ ). The acoustic echogram for the normoxic station (Stn 38) showed large schools of fish near the surface as well as near the bottom (Fig. 5a). The catch was almost exclusively Atlantic bumper (>99\%). The hypoxic edge station (Stn 55) showed high biomass at 
a)
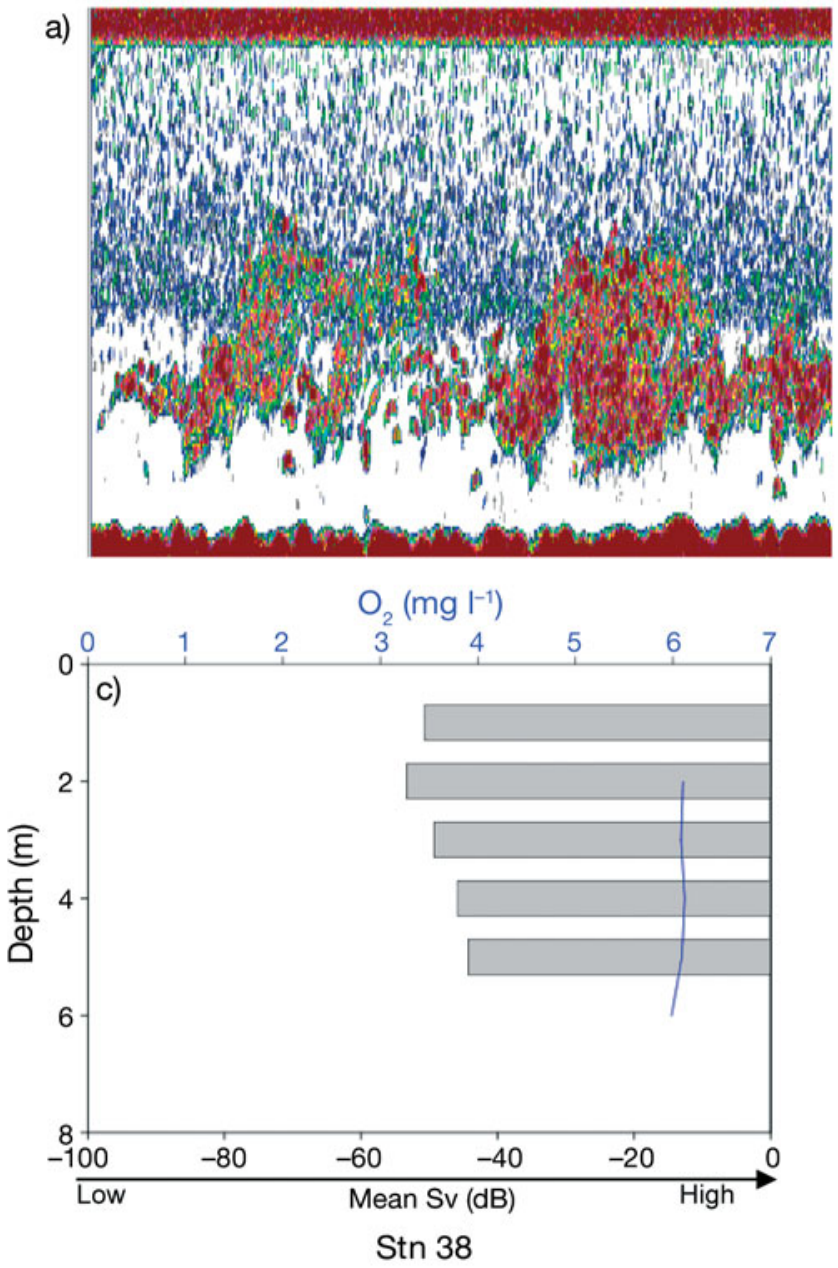

b)
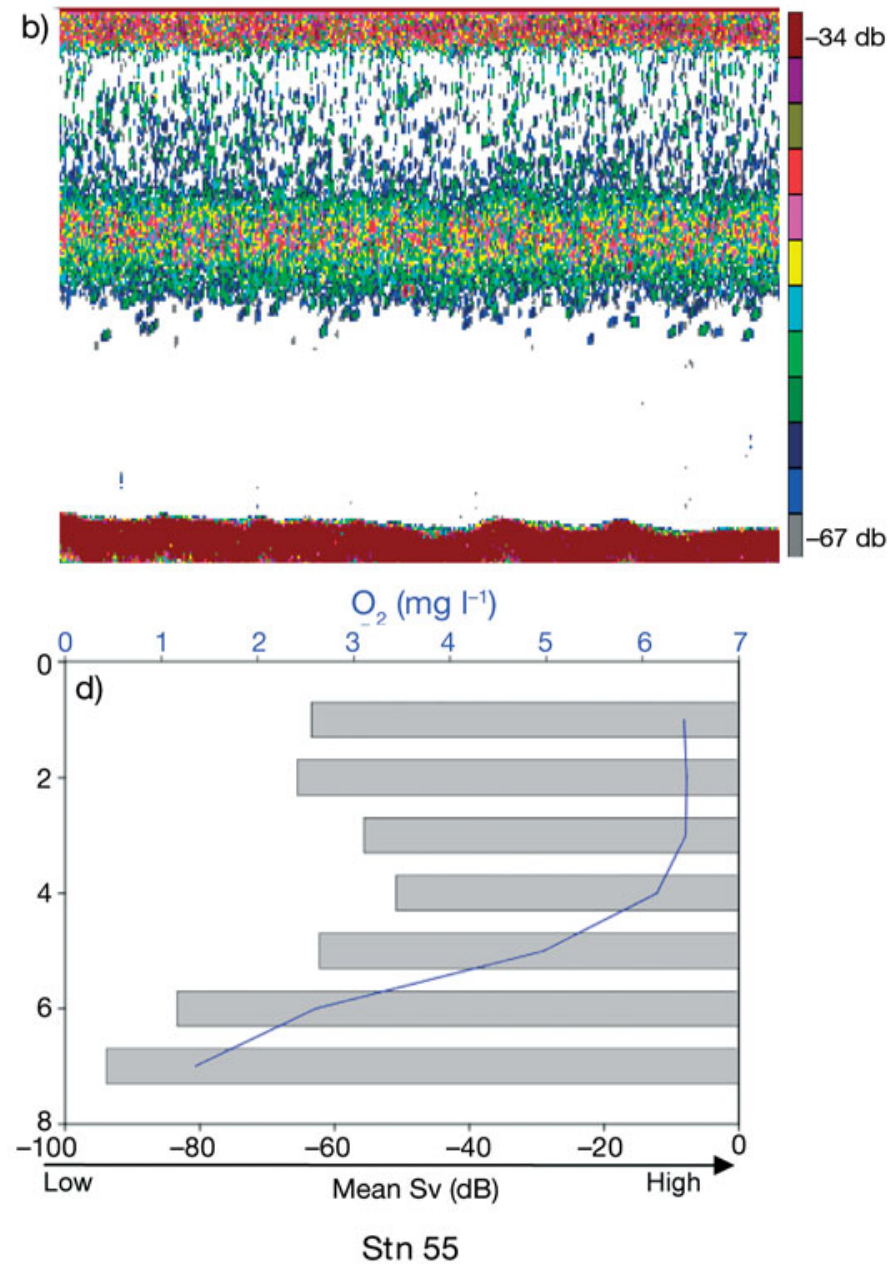

Fig. 5. Representative echograms of acoustic backscatter and the vertical distribution of backscatter and dissolved oxygen at (a,c) a normoxic station (Stn 38) and (b,d) a hypoxic station (Stn 55) on the inner Louisiana shelf. High scattering volume (Sv) is shown in red and low Sv in blue (a,b). One and $0.5 \mathrm{~m}$ at the top and bottom of the water column, respectively, were excluded from analysis. Shorter bars for the vertical profiles of binned acoustic backscatter represent higher biomass (c,d). The line is the vertical profile of dissolved oxygen averaged between beginning and ending CTD profiles at each station

the surface, with high backscatter in the middle of the water column with little biomass below (Fig. 5b); only one fish (immature cobia Rachycentron canadum) was caught at this station. The oxygen profile at the normoxic station was nearly uniform, as was acoustic biomass (Fig. 5c). The oxygen profile at the hypoxic edge station declined precipitously at $\sim 4 \mathrm{~m}$ depth, from $6.3 \mathrm{mg} \mathrm{l}^{-1}$ at the surface to $1.7 \mathrm{mg} \mathrm{l}^{-1}$ at the bottom, and was mirrored by a similar decline in acoustic biomass with depth (Fig. 5d).

To further investigate the effects of hypoxia on the vertical structure of acoustic biomass, we compared the absolute and relative depth distribution of acoustic backscatter between hypoxic and normoxic stations. At hypoxic stations, average acoustic biomass within the upper $7 \mathrm{~m}$ of the water column was greater than the mean of all stations (hypoxic and normoxic combined), while the biomass in the lower $13 \mathrm{~m}$ of the water column was lower than the mean of all stations combined (Fig. 6a). The opposite pattern occurred at normoxic stations, with greater than average acoustic biomass in the lower water column (>7 $\mathrm{m}$ depth) and lower than average acoustic biomass in the upper water column $(<7 \mathrm{~m}$ depth) compared to all stations combined.

Because these differences in vertical structure may be partly influenced by the absolute depths that were sampled, we also calculated the relative accumulation of biomass over the relative volume of vertical habitat available, and compared these cumulative distributions between normoxic and hypoxic stations. Acoustic biomass accumulated more rapidly with increasing depth (surface to bottom) at hypoxic stations compared to normoxic stations (Fig. 6b). The near-linear relationship between cumulative backscatter and depth within the water column at the normoxic stations indicates a 

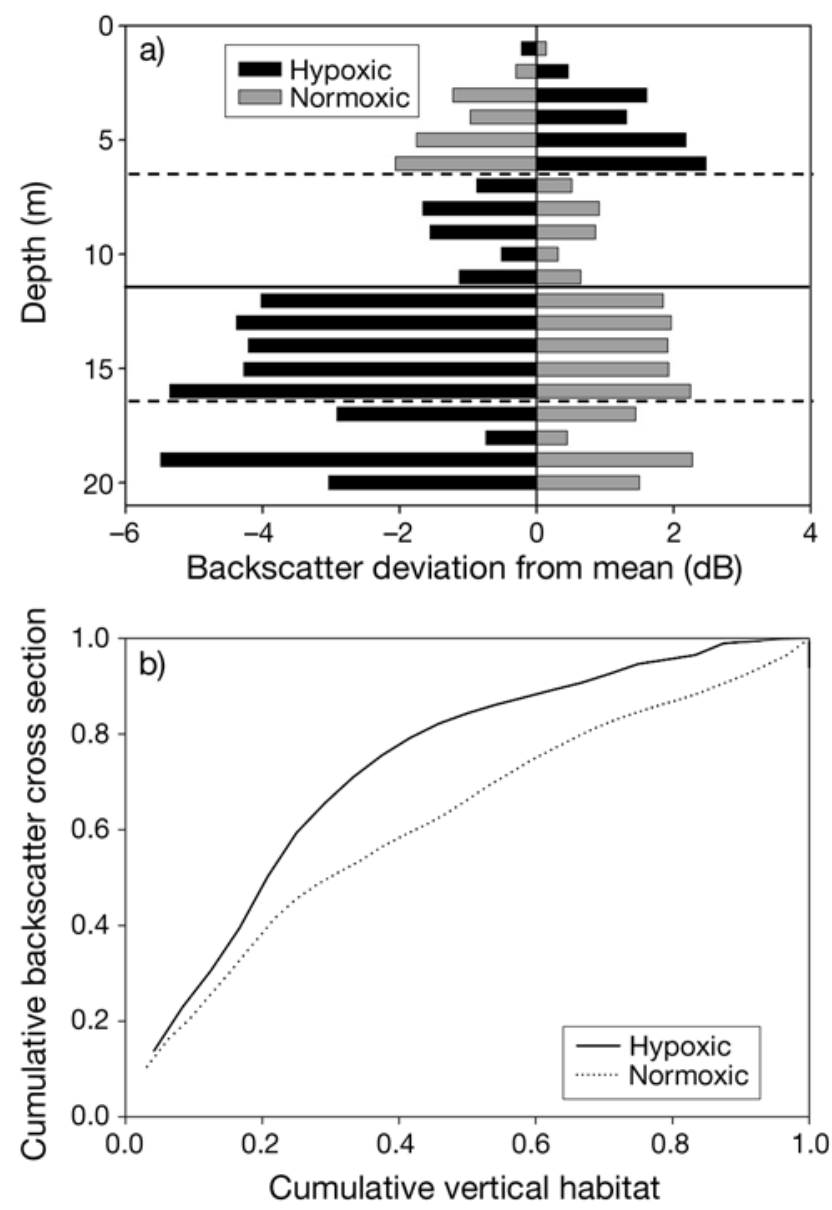

Fig. 6. (a) Absolute and (b) relative vertical distribution of acoustic biomass for hypoxic and normoxic stations on the Louisiana continental shelf. (a) Average deviations of acoustic biomass from specific depth bins in the water column for hypoxic (black) and normoxic (grey) stations relative to the mean backscatter of all stations combined are shown. Horizontal solid and dashed lines indicate the mean depth \pm SD of the oxycline $\left(2.0 \mathrm{mg} \mathrm{O}_{2} \mathrm{l}^{-1}\right)$ at hypoxic stations. Negative and positive values indicate negative and positive deviations in backscatter, respectively, relative to the logarithmic mean. (b) Cumulative distribution of backscatter (surface to bottom) versus the cumulative distribution of vertical habitat for

hypoxic (black line) and normoxic stations (dotted line)

relatively even vertical distribution of biomass, although biomass was slightly greater at the surface than at the bottom $(55 \%$ of the biomass was within the upper $40 \%$ of the water column). In contrast, $75 \%$ of the biomass at hypoxic stations accumulated within the upper $40 \%$ of the water column, consistent with vertical aggregation above the hypoxic bottom layer. The biomass ratio above and below the pycnocline was $2.5 \times$ higher at hypoxic stations $(3.90 \pm 2.8 \mathrm{SD})$ compared to normoxic stations $(1.60 \pm 1.17 \mathrm{SD}$; ANOVA, $\left.F_{1,24}=11.03, \mathrm{p}=0.0029\right)$, further supporting the hypothesis that bottom water hypoxia leads to the aggregation of biomass in the upper water column.

\section{DISCUSSION}

Prior studies have shown that low-oxygen avoidance behavior modifies the horizontal distribution of mobile organisms (Eby \& Crowder 2002, Bell \& Eggleston 2005, Craig \& Crowder 2005, Tyler \& Targett 2007). Abundance typically declines sharply when bottom DO levels are below $2.0 \mathrm{mg} \mathrm{l}^{-1}$. Field studies indicate that low-oxygen thresholds eliciting horizontal avoidance responses vary among species (Pihl et al. 1991), among life stages within species (Breitburg 1992), among systems (Decker et al. 2003), and with the spatial and temporal scale of the investigation (Bell \& Eggleston 2005). In addition, laboratory experiments suggest that some species may exhibit graded rather than threshold avoidance responses to low DO (Wannamaker \& Rice 2000, Stierhoff et al. 2006). However, organisms can also respond to bottom water hypoxia by modifying their vertical distribution in the water column (Breitburg 1994, Aku et al. 1997, Schurmann et al. 1998, Keister et al. 2000, Taylor \& Rand 2003). Hydroacoustics offers the opportunity to characterize hypoxia-induced shifts in both horizontal and vertical distributions at fine spatial and temporal scales.

Acoustically detected biomass was not statistically different inside and outside the hypoxic zone $(\leq 2.0 \mathrm{mg}$ $1^{-1}$ DO). There was a trend toward lower biomass within the hypoxic zone but the high variability in density among stations resulted in low statistical power to detect differences between hypoxic and normoxic waters $(1-\beta<0.8)$. Nonetheless, these results indicate that organisms remain within the geographic boundaries of the hypoxic zone and potentially interact with the bottom low-oxygen layer. Bottom trawl studies in the northwestern Gulf have reported low catches in hypoxic bottom waters (Pavela et al. 1983, Leming \& Stuntz 1984, Renaud 1986). For example, based on large-scale, fishery-independent trawl surveys, demersal biomass as well as abundance of particular species were low within hypoxic bottom waters but high in nearby oxygenated waters (Craig \& Crowder 2005, Craig et al. 2001, 2005). Craig \& Crowder (2005) demonstrated that Atlantic croaker aggregate at high densities in normoxic waters within $10 \mathrm{~km}$ of the hypoxic edge, and suggested that these hypoxiainduced shifts in horizontal distribution and aggregation have consequences for both trophic and fishery interactions.

From the acoustic data alone, it is not clear to what extent the biomass within the boundaries of the hypoxic zone is comprised of species avoiding the lowoxygen bottom layer or of species that are naturally abundant in the upper water column. However, a previous study in the region showed that biomass at an oil 
rig on the Louisiana shelf was greater in the upper water column during hypoxic compared to normoxic conditions despite similar total fish abundance, indicating vertical avoidance of low-oxygen bottom waters (Stanley \& Wilson 2004). Hence, hypoxia may have implications for bioenergetic processes and trophic interactions in the pelagic habitat mediated by avoidance of the bottom low-oxygen layer.

The high species richness (mean $=9$ species) in bottom trawl samples collected synoptically with the acoustic data make it difficult to unequivocally identify the species comprising the acoustically detected biomass. Overall, Atlantic bumper, Atlantic croaker, and anchovies comprised the majority of the trawl catches, but other species such as longspine porgy and sea trout were sometimes abundant. Bumper often occurred as large monospecific catches while croaker typically occurred as part of a more species-rich demersal assemblage. Since bumper are pelagic planktivores that undertake diel vertical migrations (Chaves \& Umbria 2003), they may respond to hypoxia primarily via vertical avoidance, and may thus comprise a large portion of the acoustically detected biomass above the hypoxic zone. However, other species such as anchovies and herring are also abundant in this region but may not be effectively sampled by bottom trawls. Croaker are benthivores that are strongly associated with the bottom, hence it was somewhat surprising to find large croaker numbers in areas with hypoxic bottom waters. Bell \& Eggleston (2005) found no relationship between the abundance of croaker and DO down to levels of $\sim 1 \mathrm{mg} \mathrm{l}^{-1}$. Since many of our sampled hypoxic stations were near the hypoxic edge and had $<1 \mathrm{mg} \mathrm{DO}^{-1}$, the high croaker abundance at hypoxic stations may also reflect a greater tolerance for oxygen levels $<2.0 \mathrm{mg} \mathrm{l}^{-1}$. The correlation between backscatter in the bottom $3 \mathrm{~m}$ of the water column and trawl CPUE was significant, indicating that trawl species composition could be used to help determine the species composition of acoustically detected biomass, although a large amount of unexplained variability remained. Discrepancies between acoustic backscatter and trawl CPUE might be caused by variation in trawl catchability among species, size classes, oxygen conditions, and with time of day (Michalsen et al. 1996, Casey \& Myers 1998), as well as variation in acoustic target strength (Foote 1980, Hazen \& Horne 2003, 2004).

We did not find a significant relationship between acoustic biomass and distance from the hypoxic edge. This differs from findings based on bottom trawl surveys that showed large aggregations of Atlantic croaker within 0 to $10 \mathrm{~km}$ of the hypoxic edge (Craig \& Crowder 2005). The horizontal aggregation relative to hypoxia seems to be restricted to the bottom layer rather than the entire water column - an effect that acoustics may miss, since the bottom half-meter is lost due to bottom interference. Because acoustic backscatter integrates the behavioral responses of multiple species that differ in DO tolerance and degree of aggregation in hypoxic edge habitats, trawl results could show different species-specific patterns. This study is also at a finer scale than that of Craig \& Crowder (2005), with maximum distances of only $12 \mathrm{~km}$ (vs. $100 \mathrm{~km}$ in Craig \& Crowder [2006]) from the hypoxic edge and a lower proportion of offshore stations, which may also explain some of the differences in findings. Furthermore, normoxic stations were comprised of a mix of inshore, offshore, and interior shoals surrounded by low oxygen that might each constitute different types of 'edge' habitat. Additional research, including midwater trawls and more targeted sampling near hypoxic edges, is needed to better understand the relative importance of horizontal and vertical avoidance behavior in response to bottom water hypoxia.

Two lines of evidence suggest that fish do not simply occupy the pelagic habitat above the low-oxygen bottom layer, but that hypoxia alters the vertical distribution of fishes in the water column. First, the vertical distribution of biomass was strikingly different between hypoxic and normoxic stations and did not simply reflect the loss of the bottom hypoxic layer. The amount of acoustic biomass in the upper water column was higher at hypoxic than at normoxic stations on both absolute and relative scales, consistent with the displacement of organisms in the bottom layer to higher in the water column. Similarly, the ratio of biomass above to biomass below the pycnocline was considerably higher at hypoxic compared to normoxic stations, also consistent with vertical avoidance. These results are in agreement with other studies of pelagic species that have demonstrated vertical avoidance of low-oxygen bottom water (Aku et al. 1997, Keister et al. 2000, Wanink et al. 2001, Prince \& Goodyear 2006). Additional effects of vertical avoidance behavior have also been demonstrated, including disruption of diel patterns of vertical migration (Schurmann et al. 1998), altered schooling behavior (Domenici et al. 2000, 2002), and changes in patch structure in overlying normoxic waters (Taylor \& Rand 2003). Further research is needed to determine the consequences of vertical avoidance of bottom water hypoxia for these other aspects of spatial distribution for fishes in the Gulf of Mexico.

Behavioral avoidance of hypoxia and associated shifts in vertical distribution may have implications for trophic interactions, although the direction and magnitude of these effects are difficult to predict. Lowoxygen bottom waters may serve as a refuge for hypoxia-tolerant zooplankton, leading to reduced for- 
aging efficiency of planktivorous fishes that cannot occupy the bottom hypoxic layer (Taylor \& Rand 2003, Klumb et al. 2004). Alternatively, both zooplankton and pelagic planktivores may be concentrated in surface waters as a result of behavioral avoidance of bottom water hypoxia, presumably leading to enhanced encounter rates and increased foraging efficiency by pelagic planktivores (Roman et al. 1993, Keister et al. 2000). Similar, alternative responses to bottom water hypoxia have been suggested for interactions between piscivorous fishes and planktivores (Wanink et al. 2001, Neuenfeldt \& Beyer 2006). Hypoxia-induced increases in aggregation and foraging efficiency may lead to increased growth rates of pelagic predators (Prince \& Goodyear 2006), but decreased growth due to density-dependent effects (Aku et al. 1997) or high surface water temperatures (Coutant 1985). Although outside the scope of this study, the synergistic effects of hypoxia and bycatch of Atlantic croaker and other gulf species from shrimp fisheries need to be considered in fisheries management as increased aggregations or catchability near hypoxic edges could make detection of population declines difficult.

Since the frequency and severity of hypoxic zones are increasing globally (Diaz \& Rosenberg 2008), it is becoming increasingly important to understand the linkages between low DO, behavioral responses of mobile organisms, and associated effects on trophic interactions and energy flow in coastal ecosystems. Our results indicate that fish are abundant within the geographic bounds of the hypoxic zone above the bottom hypoxic layer. Hypoxia in the Gulf is typically limited to bottom waters such that a considerable amount of the overlying water column (on average, $85 \%$ in our study) remains available as habitat. We have shown that hypoxia alters the vertical distribution of organisms, potentially altering, and perhaps intensifying, trophic interactions in the overlying pelagic habitat. Such vertical shifts in distribution have been shown to have both positive and negative effects on individual species interactions that can span multiple trophic levels. Although not well known for most marine environments, shifts in trophic interactions can also have important implications for biogeochemical processes and nutrient cycling (Schindler et al. 1997, Carpenter et al. 2001). The spatial extent of bottom water hypoxia in the Gulf has spanned an area of $<5000$ to $>20000 \mathrm{~km}^{2}$ in recent years (Turner et al. 2008), suggesting even higher variability in the volume of overlying normoxic water. This suggests that hypoxia-induced shifts in the vertical distribution of fishes and associated effects on trophic interactions in the pelagic habitat could have important implications for energy flow and nutrient cycling in this system.
Acknowledgements. We thank J. Coloso, J. Dorrance, L. Hazen, J. Jenkins, K. Larsen, J. Leonard, Z. Tait, D. Waller and the crew of the RV 'Tommy Munro' for help in conducting the research cruise; the National Marine Fisheries Service Pascagoula laboratory for use of trawl gear; and J. Condiotty of SIMRAD for use of the acoustic equipment and help with data acquisition. S. Wood provided statistical advice. Financial support for the project was provided by the National Oceanic and Atmospheric Administration (NOAA) Coastal Ocean Program under award \#NA05NOS4781197 to J.K.C., L.B.C., and A. Read (Duke University). This is NGOMEX publication number 102. E.L.H. was supported by a graduate research assistantship provided by the Census of Marine Life. The views expressed herein are those of the authors and do not necessarily reflect the view of NOAA or any of its subagencies.

\section{LITERATURE CITED}

Aku PMK, Rudstam LG, Tonn WM (1997) Impact of hypolimnetic oxygenation on the vertical distribution of cisco Coregonus artedi in Amisk Lake, Alberta. Can J Fish Aquat Sci 54:2182-2195

Balk H (2001) Development of hydroacoustic methods for fish detection in shallow water. PhD thesis, University of Oslo, Oslo, Norway

Bell GW, Eggleston DB (2005) Species-specific avoidance responses by blue crabs and fish to chronic and episodic hypoxia. Mar Biol 146:761-770

Brandt S, Mason D (2003) Effect of nutrient loading on Atlantic Menhaden Brevoortia tyrannus growth rate potential in the Patuxent River. Estuaries 26:298-309

Breitburg DL (1992) Episodic hypoxia in Chesapeake Bay: interacting effects of recruitment, behavior, and physical disturbance. Ecol Monogr 62:525-546

Breitburg DL (1994) Behavioral response of fish larvae to low dissolved oxygen concentrations in a stratified water column. Mar Biol 120:615-625

Breitburg DL (2002) Effects of hypoxia, and the balance between hypoxia and enrichment, on coastal fishes and fisheries. Estuaries 25:767-781

Breitburg DL, Loher T, Pacey CA, Gerstein A (1997) Varying effects of low dissolved oxygen on trophic interactions in an estuarine food web. Ecol Monogr 67:489-507

Burleson ML, Wilhelm DR, Smatresk NJ (2001) The influence of fish size on the avoidance of hypoxia and oxygen selection by largemouth bass. J Fish Biol 59:1336-1349

Carpenter SR, Kitchell JF, Bade D, Essington TE and others (2001) Trophic cascades, nutrients, and lake productivity: whole-lake experiments. Ecol Monogr 71:163-186

Casey JM, Myers RA (1998) Diel variation in trawl catchability: is it as clear as day and night? Can J Fish Aquat Sci 55: 2329-2340

Chaves PTC, Umbria SC (2003) Changes in the diet composition of transitory fishes in coastal systems, estuary, and continental shelf. Braz Arch Biol Techn 46:41-46

Cloern JE (2001) Our evolving conceptual model of the coastal eutrophication problem. Mar Ecol Prog Ser 210: $223-253$

> Coutant CC (1985) Striped bass, temperature, and dissolved oxygen: a speculative hypothesis for environmental risk. Trans Am Fish Soc 114:31-61

Craig JK, Crowder LB (2005) Hypoxia-induced habitat shifts and energetic consequences in Atlantic croaker and brown shrimp on the Gulf of Mexico shelf. Mar Ecol Prog Ser 294:79-94 
Craig JK, Gray CD, McDaniel CM, Henwood TL, Hanifen JG (2001) Ecological effects of hypoxia on fish, sea turtles, and marine mammals in the northwestern Gulf of Mexico. In: Rabalais NN, Turner RE (eds) Coastal hypoxia: consequences for living resources and ecosystems. Coast Estuar Stud 58:269-291

$>$ Craig JK, Crowder LB, Henwood TA (2005) Spatial distribution of brown shrimp Farfantepenaeus aztecus on the northwestern Gulf of Mexico shelf: effects of abundance and hypoxia. Can J Fish Aquat Sci 62:1295-1308

> Decker MB, Breitburg DL, Marcus NH (2003) Geographical differences in behavioral responses to hypoxia: Local adaptation to an anthropogenic stressor? Ecol Appl 13: 1104-1109

Diaz RJ (2001) Overview of hypoxia around the world. J Environ Qual 30:275-281

Diaz RJ, Rosenberg R (2008) Spreading dead zones and consequences for marine ecosystems. Science 321:926-929

Domenici P, Steffensen JF, Batty RS (2000) The effect of progressive hypoxia on the swimming activity of schooling herring. J Fish Biol 57:1526-1538

> Domenici P, Silvana Ferrari R, Steffensen JF, Batty RS (2002) The effect of hypoxia on school structure and dynamics in Atlantic herring Clupea harengus. Proc R Soc Lond B 269: 2103-2111

Domenici P, Lefrançois C, Shingles A (2007) Hypoxia and the antipredator behaviours of fishes. Phil Trans R Soc Lond B 362:2105-2121

> Eby LA, Crowder LB (2002) Hypoxia-based habitat compression in the Neuse River Estuary: context-dependent shifts in behavioral avoidance thresholds. Can J Fish Aquat Sci 59:952-965

Eby LA, Crowder LB, McClellan CM, Peterson CH, Powers MJ (2005) Habitat degradation from intermittent hypoxia: impacts on demersal fishes. Mar Ecol Prog Ser 291:249-262

Foote KG (1980) Effect of fish behaviour on echo energy: the need for measurements of orientation distributions. J Cons Int Explor Mer 39:193-201

> Foote KG (1982) Optimizing copper spheres for precision calibration of hydroacoustic equipment. J Acoust Soc Am 71:742-747

Goslee SC, Urban DL (2007) The ecodist package for dissimilarity-based analysis of ecological data. J Stat Softw 22: $1-19$

> Hastie T, Tibshirani R (1990) Exploring the nature of covariate effects in the proportional hazards model. Biometrics 46 : 1005-1016

> Hazen EL, Horne JK (2003) A method for evaluating the effects of biological factors on fish target strength. ICES J Mar Sci 60:555-562

Hazen EL, Horne JK (2004) Comparing the modelled and measured target-strength variability of walleye pollock Theragra chalcogramma. ICES J Mar Sci 61:363-377

Helly JJ, Levin LA (2004) Global distribution of naturally occurring marine hypoxia on continental margins. DeepSea Res I 51:1159-1168

Keister JE, Houde ED, Breitburg DL (2000) Effects of bottomlayer hypoxia on abundances and depth distributions of organisms in Patuxent River, Chesapeake Bay. Mar Ecol Prog Ser 205:43-59

Klumb RA, Bunch KL, Mills EL, Rudstan LG and others (2004) Establishment of a metalimnetic oxygen refuge for zooplankton in a productive Lake Ontario embayment. Ecol Appl 14:113-131

Leming TD, Stuntz WE (1984) Zones of coastal hypoxia revealed by satellite scanning have implications for strategic fishing. Nature 310:136-138
Lenihan H, Peterson C, Byers J, Grabowski K, Thayer G, Colby D (2001) Cascading of habitat degradation: oyster reefs invaded by refugee fishes escaping stress. Ecol Monogr 11:764-782

Lin X, Zhang D (1999) Inference in generalized additive mixed models by using smoothing splines. J Roy Stat Soc B 61:381-400

MacLennan DN, Fernandes PG, Dalen J (2002) A consistent approach to definitions and symbols in fisheries acoustics. ICES J Mar Sci 59:365-369

> Mantel N (1967) The detection of disease clustering and a generalized regression approach. Cancer Res 27: 209-220

> Michalsen K, Godo OR, Ferno A (1996) Diel variation in the catchability of gadoids and its influence on the reliability of abundance indices. ICES J Mar Sci 53:389-395

Neuenfeldt S, Beyer JE (2006) Environmentally driven predator-prey overlaps determine the aggregate diet of the cod Gadus morhua in the Baltic Sea. Mar Ecol Prog Ser 310: 151-163

Patriquin DG (1967) Biology of Gadus morhua in Ogac Lake, a landlocked fjord on Baffin Island. J Fish Res Board Can 24:2573-2594

Pavela JS, Ross JL, Chittenden ME Jr (1983) Sharp reductions in abundance of fishes and benthic macroinvertebrates in the Gulf of Mexico off Texas associated with hypoxia. Northeast Gulf Sci 6:167-173

Pihl L, Baden SP, Diaz RJ (1991) Effects of periodic hypoxia on distribution of demersal fish and crustaceans. Mar Biol 108:349-360

Prince ED, Goodyear P (2006) Hypoxia-based habitat compression of tropical pelagic fishes. Fish Oceanogr 15: 451-464

R Development Core Team (2005) R: a language and environment for statistical computing. R Foundation for Statistical Computing, Vienna, Austria. www.R-project.org

Rabalais NN, Turner RE, Wiseman WJ (2001) Hypoxia in the Gulf of Mexico. J Environ Qual 30:320-329

Rabalais NN, Turner RE, Wiseman WJ (2002) Gulf of Mexico hypoxia, aka 'The dead zone'. Annu Rev Ecol Syst 33: 235-263

Renaud ML (1986) Hypoxia in Louisiana coastal waters during 1983: implications for fisheries. Fish Bull 84:19-26

Rogers AD (2000) The role of the oceanic oxygen minima in generating biodiversity in the deep sea. Deep-Sea Res II 47:119-148

Roman MR, Gauzens AL, Rhinehard WK, White JR (1993) Effects of low oxygen waters on Chesapeake Bay zooplankton. Limnol Oceanogr 38:1603-1614

Schindler DE, Carpenter SR, Cole JJ, Kitchell JF, Pace ML (1997) Influence of food web structure on carbon exchange between lakes and the atmosphere. Science 277: 248-251

Schurmann H, Glaireaux G, Chartois H (1998) Changes in vertical distribution of sea bass Dicentrarchus labrax L. during a hypoxic episode. Hydrobiology 371-372: $207-213$

Simmonds EJ, MacLennan DN (2005) Fisheries acoustics. Theory and practice, 2nd edn. Blackwell Science, Oxford

Stanley DR, Wilson CA (2004) Effect of hypoxia on the distribution of fishes associated with a petroleum platform off coastal Louisiana. N Am J Fish Manag 24:662-671

Stierhoff KL, Targett TE, Miller K (2006) Ecophysiological responses of juvenile summer and winter flounder to hypoxia: experimental and modeling analyses of effects on estuarine nursery quality. Mar Ecol Prog Ser 325: 255-266 
Taylor JC, Rand PS (2003) Spatial overlap and distribution of anchovies (Anchoa spp.) and copepods in a shallow stratified estuary. Aquat Living Resour 16:191-196

Turner RE, Rabalais NN, Durbravko J (2008) Gulf of Mexico hypoxia: alternate states and a legacy. Environ Sci Technol 42:2323-2327

Tyler RM, Targett TE (2007) Juvenile weakfish Cynoscion regalis distribution in relation to diel-cycling dissolved oxygen in an estuarine tributary. Mar Ecol Prog Ser 333: 257-269

Wanink JH, Kashindye JJ, Goudswaard PC, Witte F (2001)

Editorial responsibility: Otto Kinne, Oldendorf/Luhe, Germany
Dwelling at the oxycline: does increased stratification provide a predation refugium for the Lake Victoria sardine Rastrineobola argentea? Freshw Biol 46:75-85

Wannamaker CM, Rice JA (2000) Effects of hypoxia on movements and behavior of selected estuarine organisms from the southeastern United States. J Exp Mar Biol Ecol 249: $145-163$

Wood S (2006) Generalized additive models. An introduction with R. Chapman \& Hall, London

Wu RSS (2002) Hypoxia: from molecular responses to ecosystem responses. Mar Pollut Bull 45:35-45

Submitted: September 12, 2007; Accepted: October 22, 2008 Proofs received from author(s): January 8, 2009 